\title{
El Archivo Municipal de Antequera
}

Antequera conserva en su Archivo Histórico Municipal una singular colección documental formada tras largos años de una política encaminada a la recuperación de este patrimonio. El conjunto presenta 12 grandes fondos que aglutinan desde documentación municipal a protocolos, archivos cofrades, empresariales, familiares, eclesiásticos e incluso fotográficos. Y que responde al siguiente organigrama o cuadro de clasificación:

01. Fondo municipal.

02. Fondo de protocolos notariales.

03 . Fondo parroquial.

04. Fondo de hermandades y cofradias.

05. Fondo judicial.

06. Fondo de archivos familiares.

07. Fondo Real Colegiata.

08. Fondo hemeroteca.

09. Fondo videoteca y filmoteca.

10. Fondo fotográfico.

11. Fondo archivos de empresas.

12. Fondo Cámara Agraria.

En total en la actualidad se cuenta con algo más de 35.000 unidades de instalación, que contienen documentos en soportes de toda índole, algo un tanto inusual en centros de estas características, por lo que el archivo antequerano se convierte en un referente por su diversidad y por el tratamiento innovador que se está dando a esta masa documental.

Los documentos se han conservado casi siempre en las dependencias de la Casas Consistoriales, primero en su ubicación junto al Arco de los Gigantes, en la plaza de la Feria; posteriormente en la Casa de Cabildos de la Plaza de San Francisco, para ser trasladados, en la última mitad del siglo XIX, al nuevo Palacio Consistorial de los Remedios, donde permanecerán hasta constituir

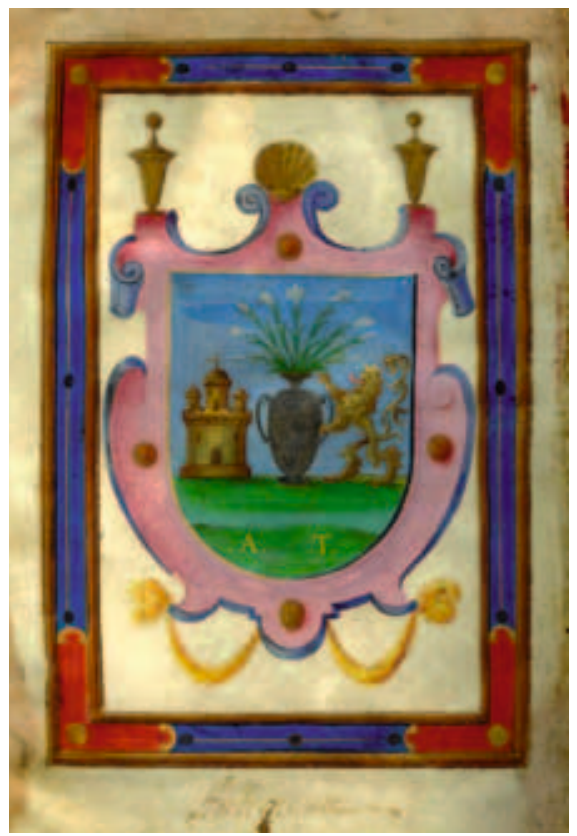

Escudo de Antequera en pergamino. Fuente: Archivo Municipal de Antequera. Real Carta de Merced confirmando las franquezas de la ciudad de Antequera, 1616 el Archivo Histórico Municipal de Antequera en 1970, siendo llevada la documentación al Palacio de Nájera, sede del Archivo y Museo, donde estará hasta 1995, fecha en la que pasa nuevamente toda la documentación al antiguo edificio del Pósito de la Ciudad, acondicionado especificamente para este fin.

En los últimos años se ha realizado una decidida apuesta por hacer del archivo de la ciudad un centro abierto y plural. Hay que destacar las numerosas actividades de difusión cultural y la incorporación plena de las nuevas tecnologías. Un ambicioso programa de gestión electrónica de documentos que se ve ahora culminado con el acceso a sus fondos documentales a través de Internet, además de contar con un taller de empleo como herramienta complementaria y a la vez formativa de especialistas en el tratamiento documental. Este taller, que se ha desarrollado en dos ocasiones bajo las denominaciones El Arca de la Memoria y Pósito de Memoria, ha consistido en una experiencia en la que se ha tratado de formar a personal especializado en las tareas de conservación y mantenimiento de un archivo. Tanto en uno como en otro se han impartido tres módulos formativos dedicados a la digitalización, documentación y restauración del material archivistico. Fruto de estos trabajos ha sido la espectacular actualización que nuestro centro ha sido capaz de asumir dando el tratamiento correcto a su masa documental. Se está planteando ya un tercer proyecto para continuar con este impulso; por un lado, para la creación de técnicos y, de otro, para mantener el equilibrio en el mantenimiento y oferta del archivo antequerano. Este proyecto nacerá bajo la denominación del Hilo de la Memoria.

El planteamiento inicial del centro, hace ya dos décadas, se basaba en establecer unas pautas encaminadas a la recuperación de un patrimonio documental del que se tenía conocimiento en la ciudad, si bien de carácter privado en muchos casos. La oferta pública ofrecia al propietario de la documentación la posibilidad de su conservación, digitalización y descripción en el Archivo de Antequera; a cambio el centro podria disponer libremente de este material y difundirlo bien a través de la Red, bien usándolo en las distintas formas de difusión y divulgación que estimara oportunas. El resultado pasado el tiempo ha sido realmente espectacular. En 1990 el Archivo de Antequera contenía tan sólo la documentación de carácter municipal, los protocolos notariales de su distrito y los archivos parroquiales. Fruto de esta política de recuperación ha sido posible tener hoy día 25 archivos de cofradias, 12 archivos familiares, 3 archivos de empresas, el archivo de la Antigua Cámara Agraria y 6 archivos fotográficos. Estos últimos de muy reciente incorporación y consistentes en el depósito de material analógico de distintos laboratorios fotográficos profesionales de la ciudad; en este sentido se han recuperado y forman parte del patrimonio documental de Antequera miles de clichés y placas fotográficas que reflejan la historia viva de la ciudad, en definitiva la historia del siglo $X X$, captada por los objetivos de distintas generacio- nes de fotógrafos locales. Posiblemente esta aportación sea la más espectacular que ha realizado nuestro archivo, tanto por la información que aporta de un periodo, como por los soportes especiales, que necesitan un trato muy especifico y unas condiciones de uso y conservación distintas al papel.

El planteamiento de un archivo local que recogiera de una forma global la distinta documentación de instituciones y personas para su conservación y uso público es hoy dia ya una realidad, y el esfuerzo realizado se ve compensado con las aportaciones que constantemente van engrosando el patrimonio de la ciudad, prueba inequivoca de la confianza que se está prestando a nuestro proyecto, avalada por los resultados obtenidos.

El fin de todo este proyecto y esfuerzo es, en definitiva, por un lado, recuperar el rico y variado patrimonio documental de la ciudad de la manera más completa posible y ofertar un espacio para su conservación. Tradicionalmente muchos archivos en nuestra comunidad han acabado vendidos al peso, en papeleras, tirados o mal vendidos a especuladores, con lo que se ha perdido parte de nuestra historia. Por otro lado, no tendría sentido alguno acumular esta masa documental sin darle una difusión adecuada; el uso de las nuevas tecnologias nos brinda la posibilidad, hace años impensable, de contar con una serie de herramientas fundamentales que nos están permitiendo llevar a cualquier parte del mundo los contenidos de nuestro archivo con unos resultados satisfactorios. Se trata de hacer uso común y ampliar al máximo la tipología de usuarios que generalmente tienen acceso a la información de los archivos, un público que hemos comprobado cada vez es más variado. El acceso a la información se hace por el portal institucional del Ayuntamiento de Antequera http://www.antequera.es, que nos da paso a la página del archivo, elemento de presentación de nuestro trabajos y que ofrece el acceso a la información y a la documentación a través de una base de datos relacional, que permite obtener información y visualizar objetos multimedia que reproducen una gran variedad de documentos. Podemos destacar, en este sentido, el acceso en formato pdf. a las actas capitulares de la ciudad desde el siglo XV al primer cuarto del siglo XX, o a la colección de carteles taurinos, o a una hasta ahora escogida selección de imágenes fotográficas, entre los casi más de un millón y medio de imágenes que son accesibles por la Red. La gran mayoría de los documentos están en ese formato universal que antes hemos indicado. En el propio archivo se puede acceder por medio de la red interna a casi el doble de documentos digitalizados, ya que en la actualidad solamente una parte está disponible en abierto. Los proyectos desarrollados y en los que se está trabajando muestran un archivo con grandes ambiciones, y con una tremenda preocupación por la recuperación y difusión del patrimonio documental.

José Escalante Jiménez

Director del Archivo Municipal de Antequera 